Commentary

\title{
Thinking Critically through Key Issues in Improving the Effectiveness of Waterlogging Prevention and Control System in China's Historic Districts
}

\author{
Shuai Si ${ }^{1,2}$, Junqi Li ${ }^{1,2, *}$, Yuzhen Wang ${ }^{3}$ and Lian Liu ${ }^{4}$ \\ 1 Key Laboratory of Urban Stormwater System and Water Environment, Ministry of Education, \\ Beijing University of Civil Engineering and Architecture, Beijing 100044, China; sishuai@bucea.edu.cn \\ 2 Beijing Energy Conservation \& Sustainable Urban and Rural Development Provincial and Ministry \\ Co-Construction Collaboration Innovation Center, Beijing 100044, China \\ 3 No.1 Sewer Maintenance Branch Company of Beijing Drainage Group, Beijing 100034, China; wyz@bdc.cn \\ 4 Beijing Waterworks Group Co., Ltd., Beijing 100031, China; linger-1l@foxmail.com \\ * Correspondence: lijunqi@bucea.edu.cn
}

check for

updates

Citation: Si, S.; Li, J.; Wang, Y.; Liu, L. Thinking Critically through Key Issues in Improving the Effectiveness of Waterlogging Prevention and Control System in China's Historic

Districts. Sustainability 2022, 14, 2913. https://doi.org/10.3390/su14052913

Academic Editors: Pierfrancesco De Paola, Francesco Tajani, Marco Locurcio and Felicia Di Liddo

Received: 9 January 2022

Accepted: 28 February 2022

Published: 2 March 2022

Publisher's Note: MDPI stays neutral with regard to jurisdictional claims in published maps and institutional affiliations.

Copyright: (c) 2022 by the authors. Licensee MDPI, Basel, Switzerland. This article is an open access article distributed under the terms and conditions of the Creative Commons Attribution (CC BY) license (https:/ / creativecommons.org/licenses/by/ $4.0 /)$.

\begin{abstract}
Solving the problem of waterlogging is of great significance to the protection of historic districts and urban renewal. To solve the problem of waterlogging, it is necessary to comprehensively consider technical aspects such as the "Major-Minor-Micro" drainage system and the connection of urban/watershed flood control systems. At the same time, attention should be paid to the role of management in the entire system. However, there are a series of problems in the current waterlogging prevention and control system in China's historic districts. The effectiveness improvement plan of the waterlogging prevention and control system is not sufficiently targeted. The various subsystems in the waterlogging prevention and control system play a role in poor coordination. The waterlogging prevention and control system does not work closely with the flood control system. Different management departments have weak coordination in the prevention and control of waterlogging. Aiming at the problems in the waterlogging prevention and control system in historic districts, this paper proposed a series of countermeasures. The waterlogging prevention and control system in historic districts should make full use of the current advanced concepts and practical experience of stormwater management. In order to enhance the role of the waterlogging prevention and control system in historic districts, specific issues should be analyzed in detail. The waterlogging prevention and control system in historic districts needs to be divided into different levels. The waterlogging prevention and control system should be aligned with historic attributes and be highly pertinent. The waterlogging prevention and control system should be closely coordinated with the larger-scale flood control system. At the same time, the intelligent management platform should be used to increase the supervision of the whole process of waterlogging in historic districts.
\end{abstract}

Keywords: historic districts; waterlogging prevention and control system; urban renewal; rainwater management

\section{Introduction}

The waterlogging prevention and control system is an important part of historic districts and plays an important role in historic districts and architectural heritage protection, urban renewal, environmental improvement, and improvement of residents' quality of life. Chinese scholars have carried out some research on the waterlogging prevention and control system in historic districts. The Beijing Municipal Planning Commission carried out systematic research on the municipal planning technology of 25 historic and cultural preservation areas such as Beijing Nanchizi, and proposed plans and construction methods for the planning and transformation of municipal facilities such as water supply, heating, gas, and drainage under special conditions in the historic districts [1]. Che W. systematically sorted out the main storm flood issues involved in the protection of Beijing's old 
city, analyzed the role and significance of storm flood control in the protection of the old city, and proposed that the modern urban storm flood control and utilization concept and technical system should be integrated into the old city protection [2]. Liu Y. analyzed the causes of waterlogging in the central city of Beijing, and proposed that the control and utilization of rainwater sources should be strengthened and the construction of urban flood storage and detention areas should be strengthened to strengthen urban flood control and comprehensive utilization of rainwater [3]. Based on the dual characteristics of both protection and development needs in historic districts, Li X. proposed technical principles and specific measures for the comprehensive planning of directly-buried municipal pipelines adapted to narrow streets in historic districts, and studied planning, design, and construction methods [4]. Li J. analyzed the problems, difficulties, ideas, and technical approaches in the construction of sponge cities in built-up areas, and proposed reasonable selection of infiltration, retention, and storage-related facilities, and a combination of decentralized and concentrated measures to solve the rainwater problem $[5,6]$.

At present, there is some research on the occurrence mechanism of urban waterlogging prevention and control, process simulation, response management, and system construction [7]. However, the problem of urban waterlogging has not been solved well, and the problem of road water accumulation and waterlogging still exists, especially in historic districts, where the problem of waterlogging is more prominent [8]. The current research on the drainage system of historic districts has not systematically analyzed the internal connections and key issues between the various links and systems involved in waterlogging. In this paper, we analyzed the key problems of waterlogging in historic districts, examined the status quo of drainage systems in historic districts, and proposed specific countermeasures to improve the efficiency of waterlogging prevention and control systems in the context of protection and renewal of historic districts from the perspective of system efficiency improvement.

\section{Dimension of Waterlogging Prevention and Control System}

System effectiveness emphasizes system thinking, and needs to coordinate closely with all units, departments, links, and subsystems to achieve certain goals in coordination. In order to improve the waterlogging prevention and control system in historic districts, we must focus on the technical and management dimensions. Regarding the technical dimension, the waterlogging prevention and control system in the historic districts involves a "Major-Minor-Micro" drainage system, a combined overflow system, and also needs to be connected to the urban/watershed flood control system. Regarding the management dimension, the waterlogging prevention and control system in the historic districts covers multiple departments, professions, and links.

\subsection{Technical Dimension of Waterlogging Prevention and Control System in Historic Districts}

The waterlogging prevention and control system is a systematic project covering the whole process of rainwater production/convergence, regulation and storage, utilization, and discharge, including three subsystems: source control system (Micro-drainage system), minor drainage system, and major drainage system [9]. Three subsystems correspond to intercepting different rainfall events: the micro drainage system controls the rainfall event up to 6 months, the micro drainage system controls the peak runoff for 2 to 5 years, and the major drainage system controls the peak runoff for 10 to 100 years [10]. For historic districts, the micro-drainage system mainly corresponds to the permeable ground and courtyard green space in the courtyard, the minor-drainage system mainly refers to the gray infrastructure such as pipes and ditches in the street, and the major-drainage system mainly corresponds to the river and lake system in the larger area, road discharge channels/undesigned channels, and urban rainwater multifunctional storage space [11-13]. The flow direction of drainage in historic districts and the response relationship between the "Major-Minor-Micro" subsystems are shown in Figure 1. 


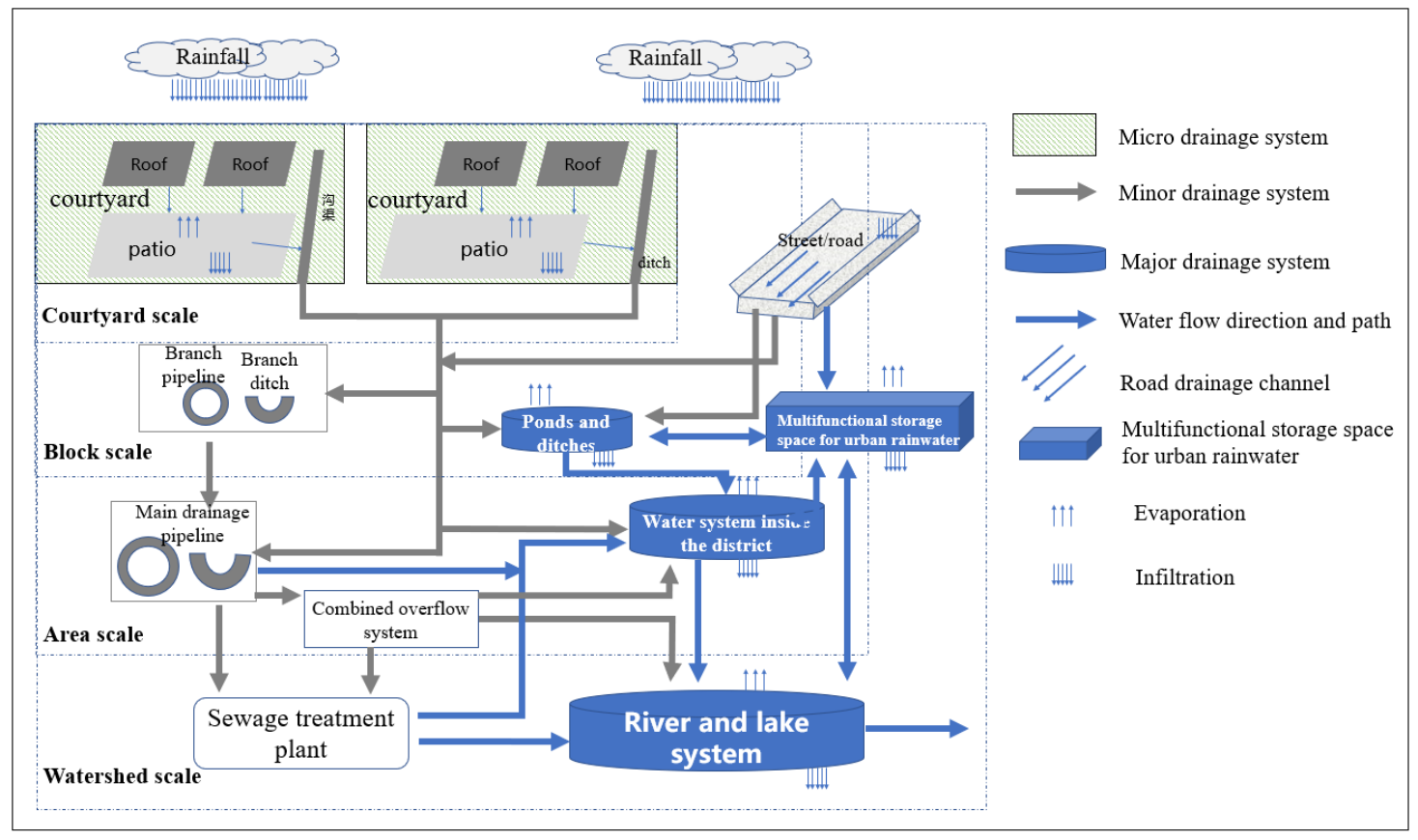

Figure 1. A schematic diagram of the "major-minor-micro" waterlogging prevention and control system in historic districts.

The waterlogging prevention and control system also needs to cooperate with the flood control system. People are accustomed to living in the location of water sources, so historic districts are often adjacent to rivers and lakes, and the increase in rainfall in the rainy season is prone to flooding. Therefore, to improve the drainage efficiency of historic sites, attention should also be paid to larger-scale flood control systems. China's design codes require that the comprehensive flood control and disaster mitigation capabilities of the central urban area meet the flood control standards of super-large cities that occur once in 100-200 years. The recurrence period of waterlogging prevention and control in megacities is once in 50 to 100 years. The waterlogging prevention and control system and the flood control system are closely linked and jointly affect the water environment and water safety of the city.

\subsection{Management Dimension of Waterlogging Prevention and Control System in Historic Districts}

The prevention and control of waterlogging in historic districts is a systematic project, which cannot be completely solved only from the engineering and technical aspects. From the perspective of government management departments, it involves cultural relic protection, planning, urban construction, environmental protection, urban management, development and reform, gardening, and emergency management. From the perspective of the disciplines covered, architectural heritage protection, architecture, planning, municipal administration, roads, and environment are all closely related. From the perspective of involving intermediate processes, it is inseparable from the links of surveying and mapping, design, planning, construction, supervision, and operation and maintenance. The solution to the waterlogging problem is inseparable from efficient management. The smooth implementation of project construction, the close integration of various industry norms and standards, and even the effective play of the role of individual structures require the cooperation of multiple departments and multiple disciplines. Scientific technical means can theoretically solve the problem of waterlogging, but the ultimate solution is inseparable from effective management [14]. The solution to the prevention and control of waterlogging is a comprehensive manifestation of the level of urban management, and it is a comprehensive indicator that highlights the level of social governance and the quality of the social environment. 


\section{Problems in the Improvement of the Effectiveness of the Waterlogging Prevention and Control System in Historic Districts}

At present, with the development of China's economy and society, the problem of waterlogging in historic districts is more prominent. In terms of water cycle, the greening rate in historic districts is generally low, the impervious surface area is large, and the natural circulation path of water is destroyed. In terms of facilities, the pipeline network/pipeline facilities are outdated, the standard is low, the renovation space is limited, and the update and maintenance are not in place [15]. In terms of the water system, the historic water system in the urban area disappeared, and the rivers and lakes were artificially separated, which caused the water discharge path to be unsmooth. In terms of management, various departments or intermediate processes are divided and cannot be well integrated. At present, some studies have carried out many program studies on some specific issues or specific projects, but these studies or programs do not consider the special attributes of historic districts protection and the core elements of improving the effectiveness of the waterlogging prevention and control system. There are generally a series of problems. They are manifested in the following four aspects.

\subsection{Lack of Pertinence in Planning and Design}

For historic districts, whether it is the selection of municipal pipelines or road layouts, planning, design, and construction have been carried out in accordance with general urban construction standards for many years, and there is a lack of special policies that coordinate with the protection goals of historic districts [16]. In recent years, this situation has improved, but the problem is still unresolved. Regarding the protection and renewal of historic districts and the prevention and control of waterlogging, China has successively issued a number of measures and standards for the central and local governments. For example, the "Urban Purple Line Management Measures" promulgated by the Ministry of Housing and Urban-Rural Development of China require that historic and cultural districts be renovated and updated, and the improvement and construction of infrastructure and public facilities should be strengthened on the premise of improving the living environment [17]. Beijing local standard "Sponge City Construction Design Standards" requires that historic and cultural districts should not be set up with runoff rainwater control indicators, should be based on the premise of protecting cultural relics and historic features, and should mainly solve the problems of local water accumulation, misconnection of pipelines, and runoff pollution [18]. On the whole, for the infrastructure construction and waterlogging problems of historic districts, the relevant regulations or standards only provide a guiding opinion, and there are no clear regulations on how to implement it. This leads to different understandings of different professionals. Judging from the current overall research, the relevant norms or standards only put forward a guiding opinion for the infrastructure construction and waterlogging problems of China's historic districts.

In the practice of improving the efficiency of the drainage system in historic districts, a "one size fits all" situation is likely to occur due to the lack of targeted methods and measures. On the one hand, the protection and renewal only pursue the protection of the style and features of the historic districts, the drainage system is not renewed in place, and the problem of waterlogging and stagnant water cannot be effectively solved. On the other hand, with the improvement of China's economic level, drainage standards have also been continuously improved. The development process of rainfall frequency based on the design of rainwater pipes reflects the continuous improvement of the design standards of urban drainage systems in China, as shown in Table 1. At the same time, some cities, especially the old urban areas and even historic districts, hope to solve the problem of waterlogging and accumulation of water by continuously improving the design standards of the pipe network and increasing the diameter of the drainage pipe network, which often increase investment [19]. At the same time, this approach has brought some damage to the historic districts and affected the normal lives of residents, but the waterlogging problem has not been effectively alleviated. 
Table 1. Evolution and Development Process of Design Rainfall Frequency of Drainage Pipes and Canals in China.

\begin{tabular}{|c|c|c|}
\hline Year & Related Design Codes and Standards & Specific Requirements \\
\hline 1953-1957 & Urban planning adopts the Soviet model & $\begin{array}{l}\text { Mainly rely on the design and construction experience of the } \\
\text { designer, } 0.33-1 \text { year }\end{array}$ \\
\hline 1963 & $\begin{array}{l}\text { Code for design of urban wastewater } \\
\text { engineering (JG11-63) }\end{array}$ & $\begin{array}{l}\text { Calculate the amount of rainwater with the design overflow period, } \\
\text { and then design the rainwater pipeline according to the settlement } \\
\text { result [20],0.33-1 year }\end{array}$ \\
\hline 1974 & $\begin{array}{l}\text { Code for design of outdoor wastewater } \\
\text { engineering (TJ14-74) }\end{array}$ & $0.33-2$ years \\
\hline 1987 & $\begin{array}{l}\text { Code for design of outdoor wastewater } \\
\text { engineering (TJ14-87) }\end{array}$ & $0.5-3$ years \\
\hline 2006 & \multirow{4}{*}{$\begin{array}{l}\text { Code for design of outdoor wastewater } \\
\text { engineering (GB50014-2006) }{ }^{1}\end{array}$} & general areas: $0.5-3$ years; important areas: $3-5$ years \\
\hline 2011 & & $\begin{array}{l}\text { Cancel the lower limit of } 0.5 \text { years; general areas: } 1-3 \text { years; } \\
\text { Important area: } 3-5 \text { years }\end{array}$ \\
\hline 2014 & & Small and medium cities: $2-3$ years; large cities: $2-5$ years \\
\hline 2016 & & $\begin{array}{l}\text { Same as the regulations in 2014, while the standard regulations } \\
\text { should adopt the upper limit }\end{array}$ \\
\hline
\end{tabular}

${ }^{1}$ The standards were revised in 2006, 2011, 2014, and 2016.

\subsection{The Sub-Systems of the Waterlogging Prevention and Control System Are Not Closely Coordinated}

Due to the historic nature and special protection of historic districts, some studies often hope to solve the problem of waterlogging at one time through gray facilities [21,22]. Some specific projects and research results focus on contemporary advanced stormwater management concepts, and one-sided pursuit of low-impact development and other source control facilities to completely solve the problem of waterlogging. These views and practices have caused the "Major-Minor-Micro" drainage system to be artificially split, resulting in insufficient integrity and systemicity of the drainage project, and various subsystems cannot be integrated to play a synergistic effect.

Historic districts are subject to relevant restrictions such as architectural heritage protection, and the development and renovation space is very limited, but the drainage system can play a synergistic effect with surrounding districts. However, in the current protection and renewal of historic districts, the protection and renewal work are often carried out on the local area of the districts. Various facilities and structures cannot be integrated and function well. In addition, there are regulation and storage facilities distributed in different places that cannot perform as needed. If it is purely for the protection of architectural heritage, it is feasible to only consider the waterlogging prevention and control system in the historic districts, but the drainage system is a systematic project and does not exist in isolation, and the surrounding neighborhoods must be considered. In particular, the overall role of the drainage system of historic districts under the same drainage districts or catchment districts should be considered.

\subsection{The Waterlogging Prevention and Control System Does Not Closely Cooperate with the Flood Control System}

Waterlogging is mainly to control the whole process of rainfall production and confluence at the urban scale, while flood control is managed on a larger scale of the river basin [23]. In China, the planning and implementation of the waterlogging prevention and control system and the flood control system belong to different management departments. In general, waterlogging is mostly local power and managed by the local government, while flood control is mostly the central power, which belongs to the Ministry of Water Resources. Due to the difference in understanding and the different subject backgrounds involved, 
in the actual management and operation process, the relevant personnel often consider the problem from the perspective of their own understanding, and there are differences in the selection of facilities and calculation methods [24]. All of the above have led to poor coordination between the role of the city's river flood control system and the waterlogging prevention and control system [25]. Coupled with the factors of architectural heritage protection, the waterlogging prevention and control system is not smoothly connected with the flood control system and with the architectural heritage protection system.

In fact, internal waterlogging and external floods are closely related, and the two are internal and external causes of each other. The causes of internal waterlogging and external floods are different. Waterlogging is due to excessive rainwater that cannot be discharged in time, especially in historic districts, which generally have a high degree of development and insufficient capacity to absorb runoff and rainwater. In addition, inadequate standards for infrastructure such as pipe networks, low-lying terrain, and heavy rainfall have made the waterlogging problem more prominent. Floods are caused by the rapid rise of rivers, lakes, and reservoirs caused by precipitation and overflowing or breaking of dams [26]. Internal waterlogging is closely related to external floods: internal waterlogging can cause external floods, and external floods can also cause internal waterlogging. In general, heavy rainfall will cause waterlogging in cities and towns, the excess water will be discharged into rivers, and the accumulation will become floods. The occurrence of floods will also increase the risk of waterlogging in downstream towns. Therefore, only starting from the waterlogging system in the historic districts cannot completely solve the waterlogging problem, and we must also pay attention to the larger-scale flood control system. The waterlogging prevention and control system and the urban flood control system work together to truly solve the waterlogging problem.

\subsection{Inadequate Coordination between Government Departments and between Different Professions}

The prevention and control of waterlogging in historic districts involves multiple departments, multiple disciplines, and multiple intermediate links, including architectural heritage protection, planning, construction, municipal administration, and management. In general, special plans will be prepared for the protection and renewal of historic districts, including specific planning content such as architectural heritage protection, water conservancy, municipal administration, and the environment, while the detailed regulatory and constructional detailed regulations will clarify the specific content of control. The government departments involved in the protection and renewal of historic districts and the planning content involved are shown in Figure 2. For this kind of systematic project of waterlogging prevention and control, all departments need to work together, and various plans and constructions should be closely connected.

In the traditional Chinese government management model, the functions of various departments are based on professional division of labor coupled with the lack of effective communication mechanisms, which are prone to fragmentation; however, in some cases, there are overlapping jurisdictions [27]. For example, the management of rivers and water systems in historic districts is related to local administrative divisions, which may belong to different departments such as urban construction, water affairs, and urban management, and the boundaries of the matters in charge of each department are sometimes unclear, especially the limits of the management area. It is easy for all departments to ignore the situation within the border area. At the same time, the points of attention of various management departments are also deviated. The architectural heritage protection department pays more attention to the protection of historic buildings and the preservation of styles and features, and less to the feasibility and operability of some infrastructure deployment. Pipe network planning and design departments often work in accordance with specifications and design standard documents and focus more on theoretical effects, paying little attention to subsequent actual operations and effect inspections. The construction unit pays more attention to the reduction of construction costs, and does not pay enough attention to the later operation and maintenance management. The lack of effective work 
connection among various business departments, proneness to prevarication, and other phenomena when problems arise restrict the improvement of the overall system efficiency.

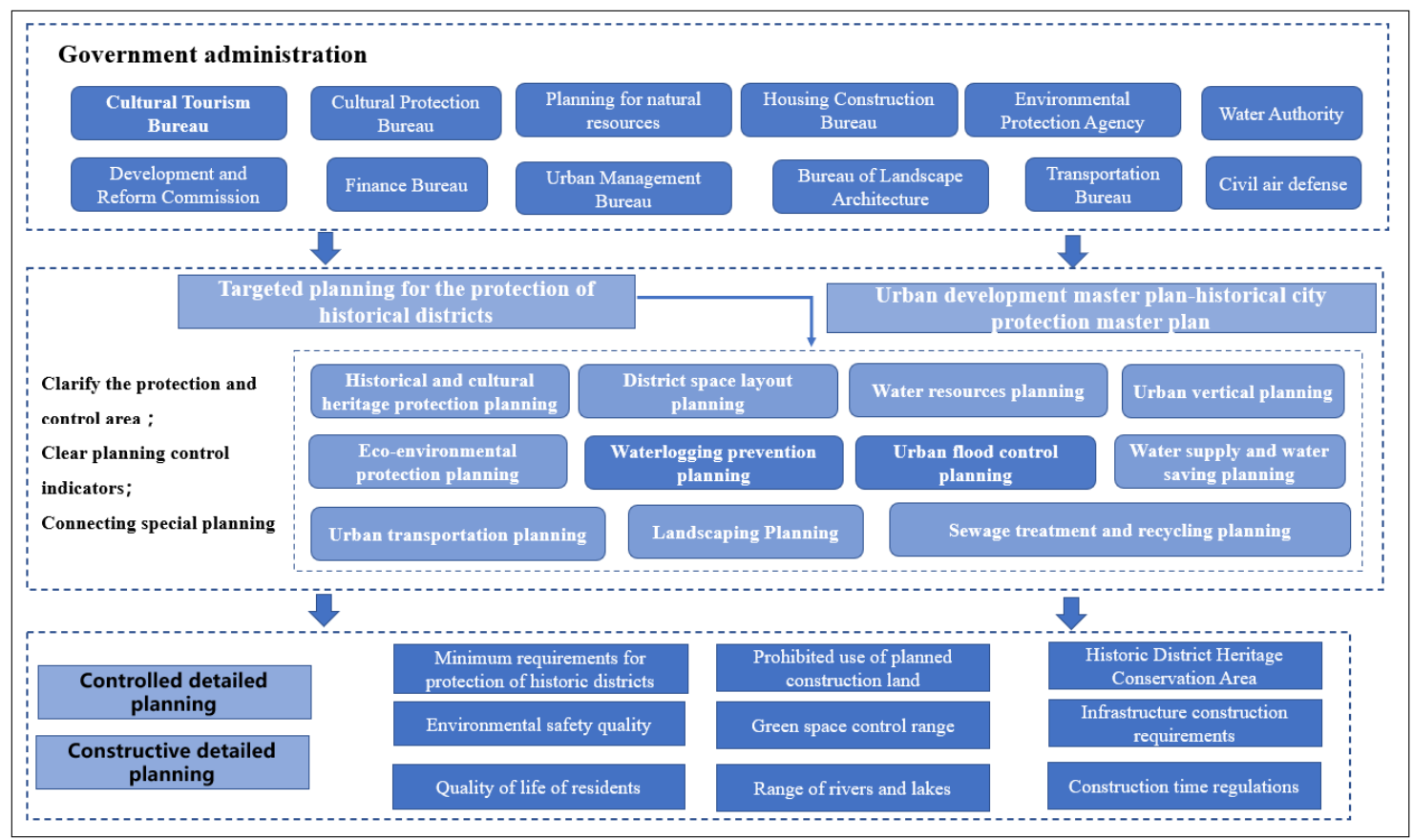

Figure 2. Drainage and Waterlogging Prevention Management and Planning Framework for China's Historic Districts.

\section{Specific Countermeasures to Improve the Effectiveness of Waterlogging Prevention and Control Systems in Historic Districts}

\subsection{Relevance and Adaptability}

The improvement of the efficiency of the drainage system in the historic districts should meet the needs of both the protection of architectural heritage and the improvement of the quality of life of residents. However, this work still has a long way to go. For example, in a historic district in Beijing, around 2014, only $68 \%$ of residents still used sewers for drainage, while the remaining $32 \%$ of households' domestic sewage was directly discharged into the street, putting pressure on street drainage and the environment [28]. Due to the special attributes of historic districts, it is necessary to adopt pertinent and applicable transformation and update technologies according to the attributes and characteristics of historic districts [29]. We should further sort out and standardize the national norms, methods, and strategies for pipeline design in historic districts based on existing conditions [30] and strengthen the diagnosis of existing pipeline network facilities based on technologies such as multi-level analysis and evaluation of collaborative diagnosis [31]. We should use model simulation and vertical optimization to improve the drainage efficiency of old alleys in collaboration with pipe trenches and road drainage [32]. We should also comprehensively consider the narrow streets and lanes space and the needs of residents, and further refine the pipeline laying sequence, arrangement method, pipe size, horizontal and vertical spacing technical methods in historic districts [33].

The current sponge city construction provides a new direction for waterlogging prevention and environmental improvement in historic districts. The construction of sponge cities clarified the division and value of annual runoff volume control in mainland China, and proposed the construction of sponge cities in accordance with local conditions [34]. The problems of waterlogging and water environment pollution exist objectively in historic districts. Therefore, it is very necessary to carry out rainwater source control for the protection of historic districts in different levels, plots, and precision. The goal of prevention and control of water safety and waterlogging in historic districts should be 
determined. At the same time, the rate of total annual runoff control in historic districts should be determined [35]. For courtyards in historic districts, different indicators can be set according to the protection levels of national laws and regulations. As shown in Table 2, the requirements for courtyard protection and renewal should be clarified, and the extent to which sponge cities in historic districts can be renewed should be clarified. For the streets in the historic districts, we can refer to the current advanced green street design concepts [36], and on the basis of preserving the street style remains and architectural heritage protection, we can set up design guides and sample atlases according to local conditions.

Table 2. Renewal requirements for protection of courtyards in historic districts.

\begin{tabular}{|c|c|c|}
\hline $\begin{array}{l}\text { Types of Courtyards in } \\
\text { Historic Districts }\end{array}$ & $\begin{array}{l}\text { The Extent of Sponge City } \\
\text { Construction Can Be Carried Out }\end{array}$ & $\begin{array}{c}\text { Specific Requirements for the Protection } \\
\text { and Renewal }\end{array}$ \\
\hline $\begin{array}{l}\text { Key cultural relics } \\
\text { protected courtyard }\end{array}$ & Low degree of renewability & $\begin{array}{l}\text { Strictly protected, within the scope of relevant } \\
\text { national laws and regulations }\end{array}$ \\
\hline Historic courtyard & Low degree of renewability & $\begin{array}{l}\text { According to the specifications and document } \\
\text { requirements, evaluate the value of the } \\
\text { courtyard heritage in detail, and carry out } \\
\text { protection and renewal according to the } \\
\text { construction age and current situation of } \\
\text { the courtyard }\end{array}$ \\
\hline General courtyard & Medium degree of renewability & $\begin{array}{l}\text { According to the overall layout and style of the } \\
\text { historic districts, take appropriate measures } \\
\text { for reconstruction }\end{array}$ \\
\hline Newly built courtyard & High degree of renewability & $\begin{array}{l}\text { It is in harmony with the overall layout and } \\
\text { style of the districts. The total amount of runoff } \\
\text { control target can be set reasonably according } \\
\text { to the courtyard conditions }\end{array}$ \\
\hline Other types of courtyards & $\begin{array}{l}\text { Take refined evaluation and } \\
\text { improvement measures }\end{array}$ & $\begin{array}{l}\text { Clarify the ownership and current conditions } \\
\text { of the property rights of the internal units of } \\
\text { the courtyard. Carry out courtyard protection } \\
\text { in a refined manner according to the } \\
\text { investigation and evaluation situation }\end{array}$ \\
\hline
\end{tabular}

The waterlogging prevention and control system in historic districts should highlight "multi-level" and "adaptability". "Multi-level" means to take different technical and management measures to prevent and control waterlogging according to the different protection requirements of the historic district. "Adaptability" means that the special attributes of heritage protection of historic districts need to be fully considered when carrying out waterlogging prevention and control work. Combined with the construction of sponge cities, a reasonable runoff volume control rate must be clarified. Through a systematic and refined approach, specific and adaptive measures are determined. In turn, the rainwater discharge path will be unblocked, with multi-channel stagnant storage and multi-channel transfer. Eventually, the unity of protection and renewal of historic districts, prevention of waterlogging, and improvement of the living environment of residents will be achieved.

\subsection{Connection of Waterlogging Prevention and Control System and Flood Control System}

For the prevention and control of waterlogging in historic districts, it is necessary to comprehensively consider the requirements of historic building heritage protection, landscape design, landscaping, and other aspects, and connect the drainage and waterlogging prevention in the urban area with the flood prevention system in the river basin.

First of all, attention should be paid to the convergence of standards. The content of urban drainage standards, waterlogging prevention standards, and flood control standards and the conditions of convergence between them should be analyzed to clarify 
the relationship between waterlogging and external flooding. Combining design water level analysis and flood volume calculation results, the boundary conditions and implementation requirements of flood control systems in historic districts should be clarified, and supporting evidence for the connection of urban flood control and river basin flood control systems provided [37]. Secondly, we should strengthen the connection of vertical design. Combined with water conservancy calculations, the layout and elevation of flood control facilities such as dykes and dams under the flood control plan should be determined [38]. Through model simulation and scientific calculations, various elevations and vertical designs of waterlogging prevention and control system facilities should be determined, and a waterlogging drainage mode of "regulation- storage, self-draining, and drainage" constructed so as to achieve multifunctional coordination and connection of flood control and drainage. Although existing simulation tools cannot directly simulate external floods and waterlogging, one-dimensional and two-dimensional mathematical models can be combined to study the response relationship between external floods and waterlogging [39]. Third, the application connection of storage and drainage facilities should be strengthened. Through comparative analysis of typical experiences and practical cases of urban drainage deep tunnel construction [40], the planning and design of drainage deep tunnel planning and construction methods and models suitable for historic districts should be explored, and a complete flood control and drainage system should be linked [41]. Deep tunnels and large-scale storage facilities can adjust the peak rainfall flow and total runoff to prevent waterlogging in urban areas. Research on the role of historic water systems in flood control and drainage, landscape effects, microclimate improvement, environmental enhancement, and historic and cultural inheritance should be intensified, and ways to achieve the convergence of flood control and drainage systems from the perspective of historic water system restoration explored [42,43]. Fourth, we should strengthen the connection of various subsystems. The layout of emission reduction facilities should be reasonably set up and optimized at the source, the drainage system and some gray infrastructure should be updated, lakes and water systems should be rationally used, and the positive effects of water system connectivity on flood control and drainage should be explored [44]. Engineering facilities and non-engineering facilities should be coordinated and cooperate with dams, reservoirs, and flood storage facilities to give full play to the overall effectiveness of the flood control and drainage system.

In the process of urbanization development, cities in developed countries and regions such as the United States, Germany, the United Kingdom, Japan, Australia, Singapore and Hong Kong have suffered from waterlogging problems [45]. Developed countries and regions have a clear concept of "Waterlogging Disaster or Local Flooding" in the drainage system [46]. Drainage and flood control in the United States is clearly composed of two parts: Urban Flooding and Watershed Flooding, whose responsibilities are the Local Government and the Federal Government respectively. The United States has paid enough attention to the connection of standards and technologies between waterlogging and external floods [47]. The international development experience of developed countries in the prevention and control of urban floods shows that attention should be paid to the connection between internal and external floods, including standards, management, and technical strategies.

\subsection{Intelligent Management Platform for Waterlogging Prevention and Control in Historic Districts}

At present, the construction of smart cities has brought new ideas and new methods to the protection and renewal of historic districts and the construction of waterlogging prevention and control systems [48]. The protection and renewal of historic districts can rely on the advantages of current informatization and comprehensively use online monitoring, geographic information system (GIS), digital models, AR technology, and advanced technologies of $5 \mathrm{G}$ Internet of Things. An intelligent management platform 
for waterlogging prevention and control in historic districts that integrates architectural heritage protection and waterlogging prevention and control should be built.

The intelligent management of waterlogging prevention and control in historic districts should include content related to architectural heritage protection (distribution of architectural heritage protection objects, important monitoring points, key monitoring indicators) and basic information of waterlogging prevention facilities (distribution of facilities, topography of catchment area, underlying surface type, elevation data). The relevant information of the objects of architectural heritage protection and the dynamic information records and data updates of the operation status of the waterlogging prevention and control system facilities can be displayed dynamically. As shown in Figure 3, the smart platform should also contain multiple databases to enable entry and upload of drawings for review, on-site inspection related materials and rectification opinions, and rectification responses of construction and maintenance management units. The intelligent management platform should also realize the real-time reporting, query, and management functions of monitoring data and manual monitoring data, and timely operate and maintain facilities and carry out inspections. It is particularly important to emphasize that the installation of various types of sensors must undergo corresponding professional assessments in advance to avoid damage to the architectural heritage. At the same time, it should also realize the informatization of emergency management plans within urban watersheds or drainage districts, with early warning and real-time information release functions.

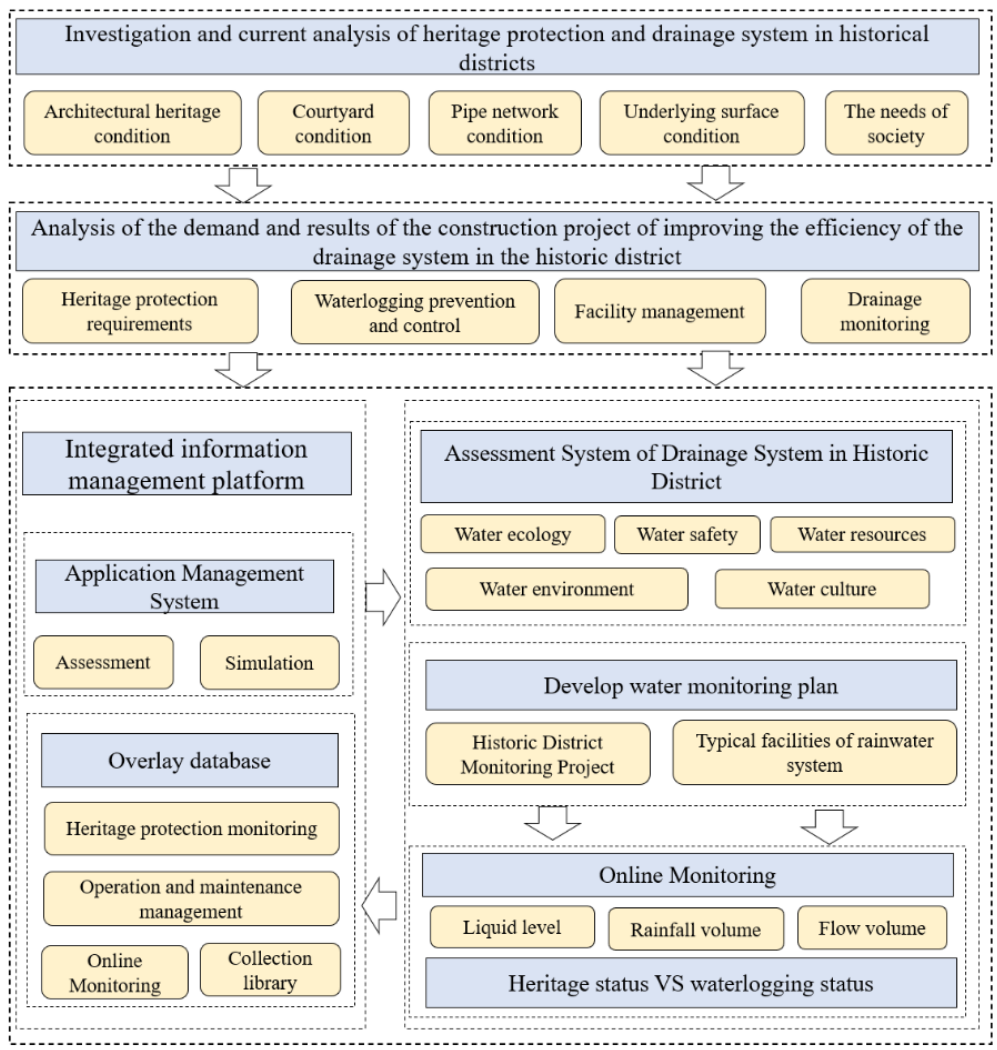

Figure 3. Intelligent management platform for waterlogging prevention and control system in historic districts.

The establishment of an intelligent management platform provides support for comprehensively grasping first-hand information and carrying out precise decision-making. At the same time, intelligent management can improve the speed of information transmission and the efficiency of resource allocation, which is of great significance to the cross-regional and cross-departmental protection and renewal of historic districts and the prevention and control of waterlogging. 


\subsection{Strengthen Management Coordination and Improve Governance Effectiveness}

The solution to the problem of waterlogging in historic districts is a comprehensive manifestation of urban management capabilities. In order to improve the effectiveness of the waterlogging prevention and control system in historic districts, improvements should be made in the following aspects. First, we should optimize the organization and work process. Functional departments or work items with similar business segments or work attributes should be reorganized and integrated. We should abandon the fragmentation of urban waterlogging control, combine the holistic governance theory to clarify the waterlogging control path in the historic districts, and form a coordinated and diversified governance body. Second, we should build a consultation mechanism and create a good communication platform. Government management departments should play an organizing and coordinating role, social experts, institutions, groups, etc. should master the technology, and the people should live in it. Therefore, in the process of preservation and renewal of historic districts, the opinions of various professional experts and the people should be widely listened to, and conservative or radical practices and ideas should be eliminated. Residents living in historic districts should be given certain opportunities to express their opinions because they are more familiar with the living environment. They clearly know which locations are prone to waterlogging and which locations are more harmful. At the same time, they can play the role of supervising maintenance, and we can rely on them to report timely when the drainage facilities are damaged. They can help the management department with timely maintenance management. Third, we should strengthen process control and supervision. The protection and renewal of historic districts is a multi-departmental, multi-professional, and interdisciplinary work. The prevention and control of waterlogging in historic districts involves many links, which means that more responsibilities and interest demands are involved. Therefore, the construction of waterlogging prevention and control system in historic districts must pay attention to process management and control. We should clarify the requirements and indicators of each link, and attach importance to process acceptance and process supervision.

For the waterlogging prevention and control system, the construction time sequence and target requirements of each protection and renewal project must be clear, as shown in Figure 4. In order to better coordinate the various departments of the government, a special comprehensive management department for the protection of historic districts can be established to be responsible for the protection and renewal of historic districts. The main work of this agency covers management, supervision, coordination, approval, service, assessment, and acceptance. For the construction of the waterlogging prevention and control system in the historic districts, under the unified dispatch and coordination of the comprehensive management department, the corresponding business departments of the cultural relics/cultural tourism, planning, housing construction, development and reform, and other government departments can carry out the design and review of the waterlogging prevention and control plan, protection planning permission, and acceptance. In contrast to construction goals such as architectural heritage protection and waterlogging prevention plans, the core indicators and construction requirements are clarified, and at the same time, the supervision and verification of various links before, during, and after the event are strengthened. Unclear responsibilities or unclear authority can be solved by the comprehensive management department of historic districts protection through coordination with all parties to solve the shortcomings of poor information communication and improve the overall governance effectiveness. 


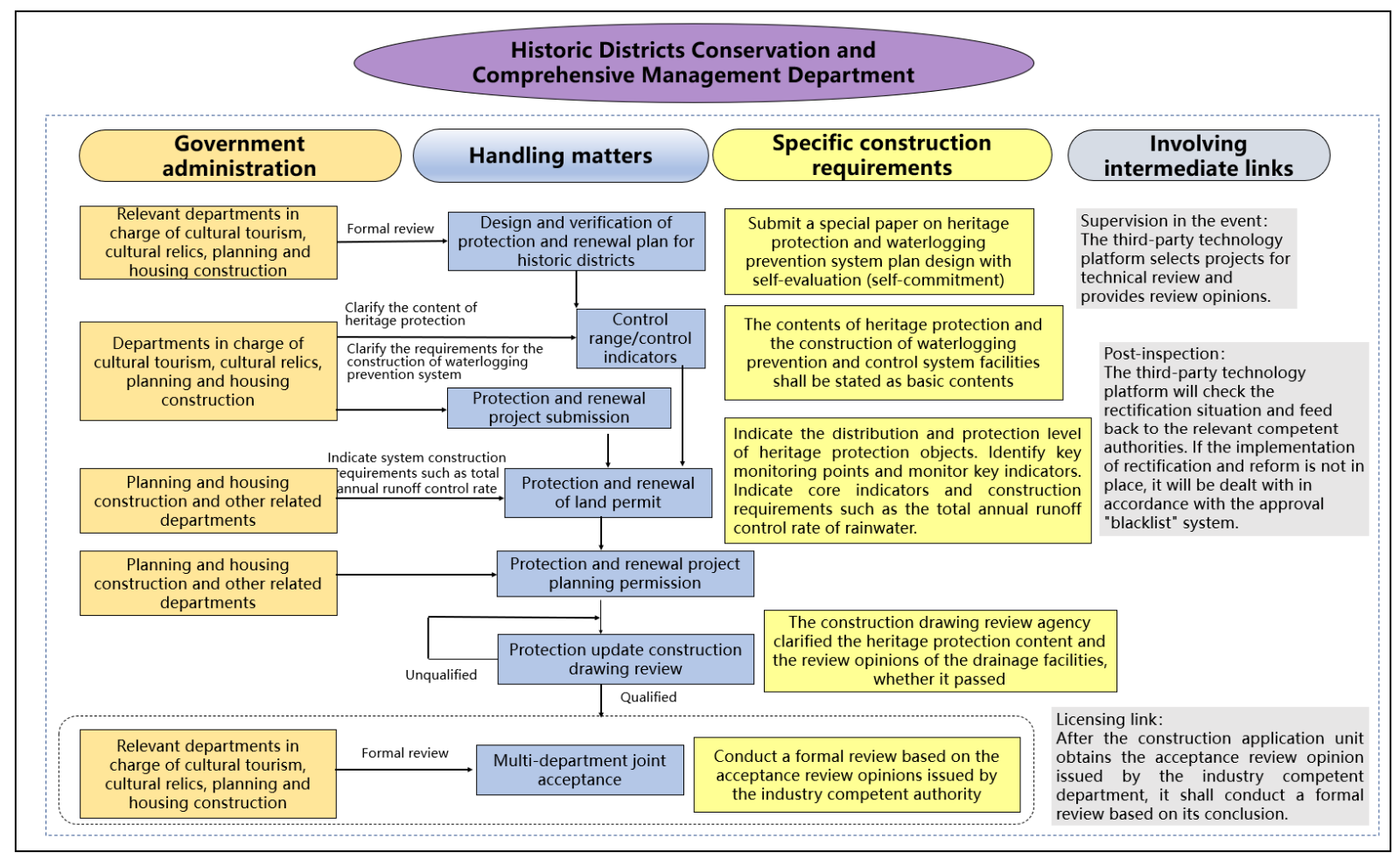

Figure 4. Departments and links involved in the construction of waterlogging prevention and control system projects in historic districts.

\section{Conclusions}

The waterlogging problem in historic districts is a systemic problem. We should coordinate the technical aspects of waterlogging prevention and control systems such as the "Major-Minor-Micro" drainage system and the joint flood control system. At the same time, it is necessary to clarify the problems existing in the management of the waterlogging prevention and control system, and improve the effectiveness of the waterlogging prevention and control system in the historic districts from the perspective of the entire system.

(1) The improvement of the effectiveness of the waterlogging prevention and control system in historic districts should coordinate the protection of architectural heritage and the improvement of the quality of life of residents. From the perspectives of courtyards and streets in historic districts, the control of rainwater sources is carried out hierarchically, by plots, and accurately.

(2) Regarding the connection between the waterlogging prevention and control system and the flood control system, consideration should be given to standards, vertical design, storage and drainage facility applications, and subsystems. At the same time, comprehensive consideration should be given to the protection of historic building heritage, landscape design, and landscaping related professional requirements to achieve the scope of towns. The drainage and waterlogging prevention and flood prevention in the river basin are coordinated and unified.

(3) In order to achieve accurate monitoring and decision-making for the protection and renewal of historic districts and the prevention and control of waterlogging in crossregional, cross-professional, and other circumstances, a joint prevention and control intelligent management platform for waterlogging prevention and control in historic districts should be built, which includes content related to architectural heritage protection and waterlogging prevention facilities. This information platform improves the speed of information transmission and the efficiency of resource allocation.

(4) In order to coordinate with multiple departments to improve in the protection and renewal of historic districts and the prevention and control of waterlogging, the orga- 
nization and work process should be optimized. We should establish a consultation and consultation mechanism, create a good communication platform, strengthen process control and supervision, implement process acceptance and control, and improve the comprehensive management ability of waterlogging prevention and control in historic districts.

Author Contributions: Methodology: J.L. and S.S.; literature review: S.S. and L.L.; drawing and modifying diagrams: S.S. and Y.W.; validation: L.L. and Y.W.; writing—original draft preparation; S.S. and J.L.; writing-review and editing: J.L. and S.S. All authors have read and agreed to the published version of the manuscript.

Funding: This research was supported by ECERC and was funded by the key project of Beijing Municipal Natural Science Foundation, China, grant number (8191001).

Institutional Review Board Statement: Not applicable.

Informed Consent Statement: Not applicable.

Data Availability Statement: No new data were created or analyzed in this study. Data sharing is not applicable to this article.

Conflicts of Interest: The authors do not have any commercial or associative interests that represent conflicts of interest in connection with the submitted work.

\section{References}

1. Research Group on Municipal Infrastructure Planning of Beijing Old City Historical and Cultural Protection Zone. Research on Municipal Infrastructure Planning of Beijing Old City Historical and Cultural Conservation Area; China Architecture \& Building Press: Beijing, China, 2006; pp. 23-91. (In Chinese)

2. Che, W.; Tang, L.; Li, H. Rain and Flood Control and Utilization in the Protection of Beijing Old City. Beijing Plan. Constr. 2012, 5 , 46-52. (In Chinese)

3. Liu, Y.; He, Y. Discussion about urban stormwater control in Beijing. Urban Stud. 2012, 19, 4-7.

4. Li, X. Research on Adaptability Technology of Comprehensive Planning of Directly Buried Pipelines in Historic Districts. WEWE 2013, 39, 99-104. (In Chinese)

5. Zhang, Y.; Li, J.; Wang, W. Analysis of Several Major Puzzles and Countermeasures of Sponge City Construction. China Water Wastewater 2016, 32, 7-11.

6. Li, J.; Huang, J.; Wang, W. Problem-oriented sponge city development strategy in urban built-up area. Water Wastewater Eng. 2017, 43, 41-46.

7. Han, H.; Jiang, R.; Xie, J. Research progress of the urban water-logging in China based on bibliometrics. J. Water Resour. Water Eng. 2017, 28, 134-138.

8. Chen, W.; Gao, S.; Zhang, Y. Fragmentation of Urban Waterlogging Management and Its Breakthrough: Based on Holistic Governance Theory. Urban Dev. Stud. 2019, 26, 84-90.

9. Che, W.; Yang, Z.; Zhao, Y.; Li, J. Analysis of urban flooding control and major and minor drainage systems in China. China Water Wastewater 2013, 29, 13-19.

10. Guo, J.C.Y. Urban Flood Mitigation and Stormwater Management; CRC Press: Boca Raton, FL, USA, 2017; pp. 115-167.

11. Butler, D.; Davies, J. Urban Drainage 4th; CRC Press: Boca Raton, FL, USA, 2018; pp. 237-252.

12. Li, J.; Wang, Y.; Wang, W. Urban roads for major drainage system planning-design methods and cases. Water Wastewater Eng. 2017, 43, 18-24.

13. Li, J.; Meng, G.; Che, W. On regulation, reservation and practical calculation in urban rainwater utilization. Water Wastewater Eng. 2007, 33, 42-46.

14. Lu, J.; Li, Z.; Peng, J. Discussion on Waterlogging Control Measures in China's Megacities. Water Wastewater Eng. 2015, 41, 93-97. (In Chinese)

15. Jia, H.; Ma, H.; Sun, Z. A closed urban scenic river system using stormwater treated with LID-BMP technology in a revitalized historical district in China. Ecol. Eng. 2014, 71, 448-457. [CrossRef]

16. Wang, Y. Reconstruction of Order and Meaning-Thought on Current Protection of Historical Street Blocks. Planners 2006, 9 , 73-75.

17. Wang, G. Historical city protection and planning management of urban purple line. Shanxi Archit. 2008, $34,61-63$.

18. Hui, L.; Ding, L.; Ren, M. Sponge City Construction in China: A Survey of the Challenges and Opportunities. Water 2017, 9, 594.

19. Hao, T.; Kong, Y. Dilemma and Reconstruction of Urban Drainage System. City Plan. Rev. 2019, 43, $103-107$.

20. Li, S. Discussion on the Calculation of Rain Runoff in Code for Design of Outdoor Wastewater Engineering. China Water Wastewater 2017, 33, 37-39. 
21. Lu, M.; Bi, Y.; Dong, S. Adaptability Planning Strategy of Municipal Water Supply and Drainage Pipelines for Conservation Planning of Historical and Cultural Blocks. Munic. Eng. 2018, 3, 168-171.

22. Fei, Y. Technology about Rainwater Seepage Wells and Technology about Diversion of Rainwater and Sewage in Historic Block. Master's Thesis, Yangzhou University, Yangzhou, China, 2019.

23. Zhang, C.; Lü, Y.; Chen, Y. Interpretation of Technical code for urban flooding prevention and control. Water Wastewater Eng. 2017, 43, 55-59.

24. He, W.; Li, C. Study of harmonious relationship about "municipal drainage, drain waterlogging, flood control" in city waterlogging. Water Wastewater Eng. 2015, 41, 85-88.

25. Pan, Z. Connection of Urban Inland River Flood Control and Drainage Waterlogging Prevention Function. Urban Roads Bridges Flood Control 2019, 10, 98-101.

26. Xie, Y. Development of drainage planning in view of frequent urban waterlogging disasters. City Plan. Rev. 2013, 37, 45-50.

27. Leat, D.; Stoker, G. Towards Holistic Governance: The New Reform Agenda; Palgrave Macmillan: London, UK, $2002 ;$ pp. $271-273$.

28. Sun, S.; Yang, C.; Tian, Z. Poorly Preserved Historical District Preservation and Renovation: Changxindian Historical District, Beijing. Planners 2015, 2, 74-79.

29. Chen, X. The Theoretic Construction of Contemporary Appropriate Technology Concept. New Archit. 2005, 6, 69-72.

30. Deng, R. Layout Design and Technical Strategy of Municipal Water Supply and Drainage Pipeline. Build. Technol. Dev. 2018, 45, $57-58$.

31. Wu, W.; Guan, Y.; Chen, B. Preliminary Study on Diagnostic Techniques of Drainage System Performance in Old Towns. China Water Wastewater 2010, 26, 59-68.

32. Zeng, Y. Research on Rainwater and Sewage Diversion Transformation in the Hutong Cottage Area of Beijing Old Town. China Water Wastewater 2020, 36, 56-60.

33. Wang, G.; Li, H. Analysis on Waterproof and Drainage Systems of Pit House in the West of Henan Province. Appl. Mech. Mater. 2012, 238, 482-485. [CrossRef]

34. Jia, H.; Zheng, W.; Zhen, X. China's Sponge City construction: A discussion on technical approaches. Front. Environ. Sci. Eng. 2017, 11, 18. [CrossRef]

35. Kang, D.; Ye, Q. Study on Evaluation and Decomposition of Volume Capture Ratio of Annual Rainfall in Sponge City. China Water Wastewater 2015, 31, 126-129.

36. Huang, X.; Song, Y.; Chen, Y. Promoting the Construction of Sponge City by Developing Green Streets: Learning from the Experience of the United States. Urban Plan. Int. 2018, 33, 120-127.

37. Zhang, C.; Zhang, L.; Mo, Z. Discussion on coordination of control systems between urban flooding and river basin flooding in new era. Water Wastewater Eng. 2020, 46, 9-13.

38. Liu, Z.; Huang, Z.; Xu, H. Urban Flood Control and Drainage Plan Based on the Design Concept of the Vertical Elevation. Guangdong Water Resour. Hydropower 2015, 6, 36-40.

39. Chen, P.; Zhang, J.; Sun, Y.Y.; Liu, X.J. Discussion on application of superposition of 1-D and 2-D coupling model for dike failure due to outside flood and water-logging model to flood control protection area. Water Resour. Hydropower Eng. 2017, 35, 89-94.

40. Lin, Z. Application of Deep Tunnel Drainage System in Urban Drainage Planning. Urban Roads Bridges Flood Control 2014, 5 , 143-147.

41. Huang, M.; Zhang, Z.; Tan, Z. Planning, Design and Construction of Deep Underground Tunnel for Flood Control and Drainage in Urban Areas in China. Tunn. Constr. 2017, 37, 946-951.

42. Zhao, X.; Zhou, Y.; Zhou, P. Discussion on Restoration of Historical Water System Based on "Urban Double Restoration" of Jingdezhen City Guidance. China Water Wastewater 2019, 35, 36-41.

43. Xue, F.; Yang, R.; Ma, H. Beijing Center Area Historical Water Corridor Restoration from the Perspective of Ecological Wisdom. Chin. Landsc. Archit. 2019, 35, 61-66.

44. Li, D.; Pan, J.; Chen, H. Influence of River Connecting Project on Flood Control and Drainage Analysis Based on Two-Dimensional Model. Yellow River 2016, 38, 31-33.

45. Lü, Y.P.; Yang, K.; Che, Y.; Shang, Z.Y.; Zhu, H.F.; Jian, Y. Cost-effectiveness-based multi-criteria optimization for sustainable rainwater utilization: A case study in Shanghai. Urban Water J. 2013, 10, 127-143. [CrossRef]

46. Chen, Z.; Lv, Y.; Yan, C.; He, X.; Zhi, X. Inspirations of International Technology and Standard Systems of Drainage Systems to China. Stand. Eng. Constr. 2014, 6, 42-47.

47. U.S. Department of Transportation. Urban Drainage Design Manual, 3rd ed.; Hydraulics Engineering Publication: Washington, DC, USA, 2009.

48. Yu, Y.; Gao, H.; Wang, G. "Micro Centers" Revitalized the Historic District: Study on the Renewal of the Suzhou Xuanqiaoxiang Historical District Against the Background of "Smart City". Urban Dev. Stud. 2017, 24, 35-40. 